Article

\title{
Improvement of Stable Restorer Lines for Blast Resistance through Functional Marker in Rice (Oryza sativa L.)
}

\author{
Jegadeesan Ramalingam 1,2,*, Savitha Palanisamy ${ }^{2}$, Ganesh Alagarasan ${ }^{2}$, \\ Vellaichamy Gandhimeyyan Renganathan ${ }^{1}$, Ayyasamy Ramanathan ${ }^{3}$ \\ and Ramasamy Saraswathi ${ }^{3}$ \\ 1 Department of Biotechnology, Agricultural College and Research Institute, \\ Tamil Nadu Agricultural University, Madurai 625104, India; vgrenga@gmail.com \\ 2 Centre for Plant Molecular Biology and Biotechnology, Tamil Nadu Agricultural University, \\ Coimbatore 641003, India; saviagri@gmail.com (S.P.); alagarasan.ganesh@hotmail.com (G.A.) \\ 3 Department of Rice, Centre for Plant Breeding and Genetics, Tamil Nadu Agricultural University, \\ Coimbatore 641003, India; nathanram@rediffmail.com (A.R.); sarasrice2004@yahoo.co.in (R.S.) \\ * Correspondence: ramalingam.j@tnau.ac.in
}

Received: 15 July 2020; Accepted: 26 August 2020; Published: 27 October 2020

\begin{abstract}
Two popular stable restorer lines, CB 87 R and CB 174 R, were improved for blast resistance through marker-assisted back-cross breeding (MABB). The hybrid rice development program in South India extensively depends on these two restorer lines. However, these restorer lines are highly susceptible to blast disease. To improve the restorer lines for resistance against blasts, we introgressed the broad-spectrum dominant gene Pi54 into these elite restorer lines through two independent crosses. Foreground selection for Pi54 was done by using gene-specific functional marker, Pi54 MAS, at each back-cross generation. Back-crossing was continued until $\mathrm{BC}_{3}$ and background analysis with seventy polymorphic SSRs covering all the twelve chromosomes to recover the maximum recurrent parent genome was done. At $\mathrm{BC}_{3} \mathrm{~F}_{2}$, closely linked gene-specific/SSR markers, DRRM-RF3-10, DRCG-RF4-8, and RM 6100, were used for the identification of fertility restoration genes, $R f 3$ and $R f 4$, along with target gene (Pi54), respectively, in the segregating population. Subsequently, at $\mathrm{BC}_{3} \mathrm{~F}_{3}$, plants, homozygous for the Pi54 and fertility restorer genes ( $R f 3$ and $R f 4$ ), were evaluated for blast disease resistance under uniform blast nursery (UBN) and pollen fertility status. Stringent phenotypic selection resulted in the identification of nine near-isogenic lines in CB $87 \mathrm{R} \times \mathrm{B} 95$ and thirteen in CB $174 \mathrm{R} \times \mathrm{B} 95$ as the promising restorer lines possessing blast disease resistance along with restoration ability. The improved lines also showed significant improvement in agronomic traits compared to the recurrent parents. The improved restorer lines developed through the present study are now being utilized in our hybrid development program.
\end{abstract}

Keywords: rice; blast; fertility restoration; functional marker; marker-assisted back-cross breeding

\section{Introduction}

The major goal of rice production is to fulfill the demand for the growing population and improve food security. Among various genetic approaches available today, hybrid rice technology is the most promising and accepted strategy for improving the rice productivity [1]. However, the hybrid rice production system suffers from various biotic stresses including fungal and bacterial diseases [1,2]. Among which, fungal blast (Magnaporthe oryzae), caused by an ascomycete fungus, is one of the major biotic diseases of rice contributing to yield loss up to 10-30\% globally [3-7]. In India the disease, under severe and favorable conditions, can cause yield losses ranging from 74 to $100 \%$ [8-10]. 
The survivability and high multiplication ability of fungal blasts even in harsh environmental conditions further limit the control of the disease [11]. Deployment of host plant resistance against biotic stress is considered to be a viable strategy for managing the disease in hybrid rice production [12]. However, there is a paucity of high-yielding, disease resistant hybrids/varieties available currently. Up to now, more than 100 genes conferring resistance to blasts have been identified on the rice chromosomes 6 , 11, and 12; however, very few of them were introgressed into popular rice varieties [12]. The high variable nature of the pathogen $M$. oryzae leads to frequent emergence of new virulent races resulting in loss of resistance within 3-5 years of cultivation. Currently, Pi54, a major dominant resistant (R) gene reported to confer broad spectrum resistance against geographically diverse strains of M. oryzae $[2,13,14]$. The Pi54 gene located on chromosome 11 has a unique zinc finger domain, besides LRR (Leucine-rich repeat) domain $[15,16]$. The gene triggers up-regulation of many defense response genes and transcription factors during disease reaction [17]. At the same time, this cytoplasm-localized NBS-LRR domain type (R) gene does not express constitutively in the plant tissues and is expressed only during the recognition of a pathogen-associated molecular pattern (PAMP) from the pathogen [18]. Considering these, Pi54 was selected as the target resistance gene for introgression into the restorer lines, CB $87 \mathrm{R}$ and CB $174 \mathrm{R}$.

The general commercial rice hybrid seed production in India follows a three-line approach involving a male sterile (CMS) line, a maintainer line, and a restorer line. Two popular rice hybrids, $\mathrm{CORH} 3$ and CORH 4, released by the Tamil Nadu Agricultural University for cultivation, were reported to be susceptible against blasts and bacterial blight (BB) diseases. Recently, the male sterile lines CO 2A, $\mathrm{CO} 23 \mathrm{~A}$, and CO $24 \mathrm{~A}$ (involved in the development of rice hybrids) were introgressed bacterial blight-resistance genes, $x a 5, x a 13$, and $\mathrm{Xa21}$, through functional marker-assisted back-cross breeding (MABB) [19]. However, the restorer lines utilized for hybrid development remain susceptible to both blasts and bacterial blight. Therefore, in the present study, we report the improvement of restorer lines to develop hybrids resistant to blasts. The donor parent, B 95 (a line developed from B 95-1 x Tetep), carrying the Pi54 gene, tested through All-India Co-ordinated Plant Pathology trials across India has demonstrated broad-spectrum disease resistance against blasts (AICRIP, 2002-2014). Based on this confirmation, the MAS (Marker-assisted selection) program was formulated to introgress the blast resistance gene (Pi54) while maintaining fertility restoration ( $R f 3$ and $R f 4$ ) genes into popular restorer lines of CB $87 \mathrm{R}$ and $\mathrm{CB} 174 \mathrm{R}$ in order to develop agronomically superior hybrid rice genotypes for both fungal blasts and bacterial blight resistance.

\section{Materials and Methods}

\subsection{Plant Materials}

Two stable restorer lines, CB $87 \mathrm{R}$ and CB $174 \mathrm{R}$, which are predominantly employed in the hybrid rice program in South India, were used as recurrent parents. Utilizing these lines, two rice hybrids, CO RH 3 (CO 2A/CB $87 \mathrm{R}$ ) and CO RH 4 (CO 23 A/CB 174 R), were recently released from this center for farmers' cultivation. These hybrids are mostly preferred by the farmers of South India, because of their high seed setting and high yield (6600 and $7348 \mathrm{~kg} / \mathrm{ha}$, respectively), but they are highly susceptible to blast infection. The line B 95 (B 95-1 $\times$ Tetep) was used as the donor parent for Pi54 in two independent back-cross breeding steps, and two restorer lines, CB 87 R and CB 174 R, as the recurrent parents. In addition, Tetep as positive check and IR 24 as negative check were used in the screening program. The schematic steps for the introgression of blast resistance genes into restorer lines are presented in Figure 1. 


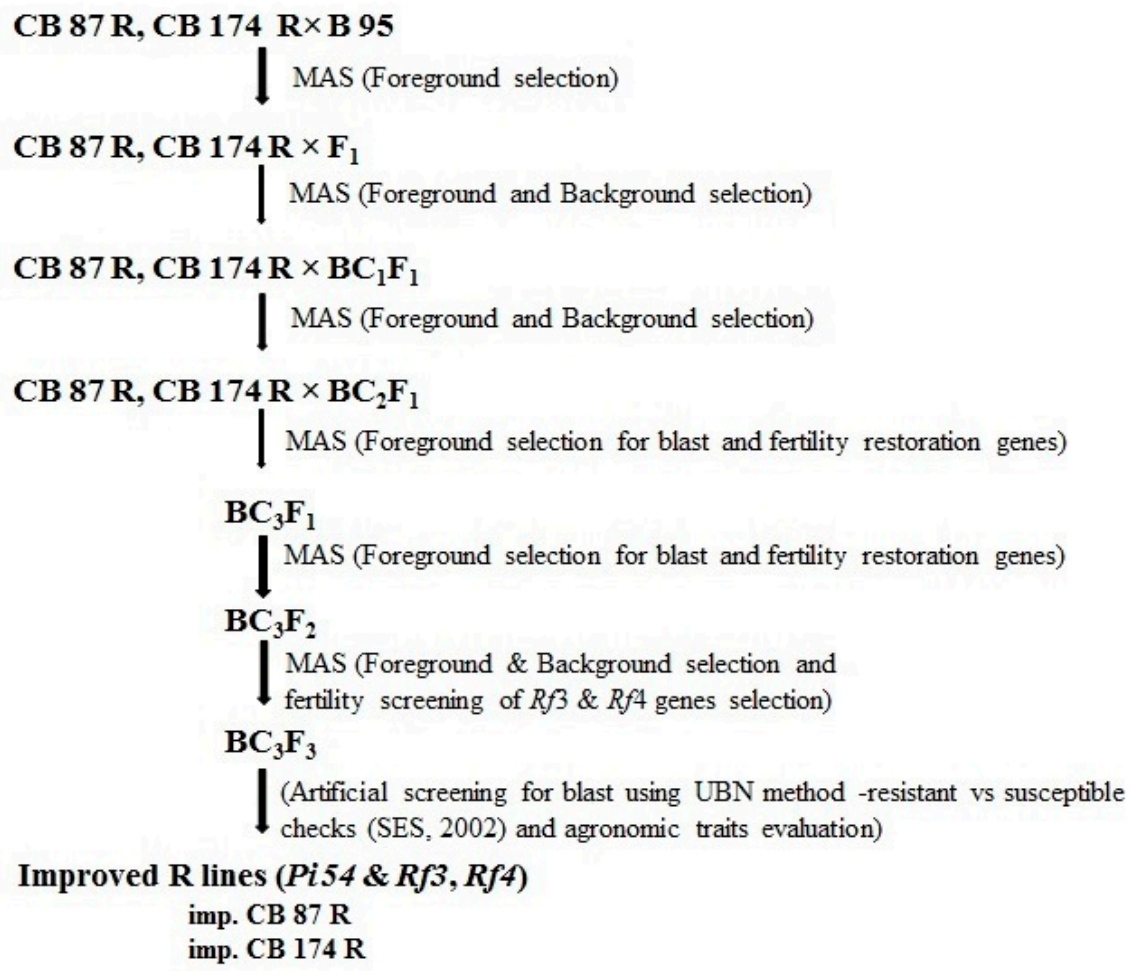

Figure 1. Schematic steps for introgression of blast resistance genes into restorer lines through marker-assisted selection Progenies homozygous for blasts (Pi54) and fertility restoration (Rf3, Rf4) were evaluated for agronomical traits and agro-morphological traits.

\subsection{Marker-Assisted Selection for Blasts and Fertility Restoration Genes}

Marker-assisted back-cross breeding program was adopted to transfer Pi54 into two stable restorer lines, CB $87 \mathrm{R}$ and CB $174 \mathrm{R}$. The fungal blast susceptible restorer lines, CB $87 \mathrm{R}$ and CB $174 \mathrm{R}$, were crossed with the donor resistant line, $\mathrm{B} 95$. Back-crossing was carried out up to $\mathrm{BC}_{3}$ generation. The PCR-based functional marker, Pi54 MAS [20], was used to identify the heterozygous nature of hybrids at $\mathrm{BC}_{1} \mathrm{~F}_{1}$ and subsequent back-cross generations $\left(\mathrm{BC}_{2}\right.$ and $\left.\mathrm{BC}_{3}\right)$ (Table 1). One hundred and fifty-six SSR (simple sequence repeat) markers (Supplementary Table S1) were used to recover the recurrent parent background in each back-cross generation. A single $\mathrm{BC}_{3} \mathrm{~F}_{1}$ plant with high recurrent genome in both the crosses was self-pollinated to produce $\mathrm{BC}_{3} \mathrm{~F}_{2}$. The segregating population was screened with Pi54 MAS to identify homozygous plants. In addition, to verify fertility restoration genes, $R f 3$ and $R f 4$, linked/gene-specific markers were used (Table 1).

Table 1. Details of markers used for blast resistance and fertility restoration.

\begin{tabular}{|c|c|c|c|c|c|c|c|c|}
\hline S.No & $\begin{array}{l}\text { Marker } \\
\text { Types }\end{array}$ & Primer & $\begin{array}{l}\text { Primer Sequences } \\
\qquad 5^{\prime} \rightarrow 3^{\prime}\end{array}$ & $\begin{array}{c}\text { Annealing } \\
\text { Temperature } \\
\left({ }^{\circ} \mathrm{C}\right)\end{array}$ & $\begin{array}{l}\text { Amplified } \\
\text { Product } \\
\text { Size (bp) }\end{array}$ & $\begin{array}{c}\text { Base } \\
\text { Pair/cM }\end{array}$ & $\begin{array}{l}\text { Chromosomal } \\
\text { Location }\end{array}$ & Citation \\
\hline \multicolumn{9}{|c|}{ Blast Marker } \\
\hline 1 & Functional & Pi54 MAS & $\begin{array}{l}\text { F- CAATCTCCAAAGTTTTCAGG } \\
\text { R-GCTTCAATCACTGCTAGACC }\end{array}$ & $56^{\circ} \mathrm{C}$ & 359 & - & 11 & [20] \\
\hline \multicolumn{9}{|c|}{$R f_{3}$ Locus } \\
\hline 2 & SSR & DRRM-RF3-10 & $\begin{array}{c}\text { TCTGTGCATTGCCTGAACAT } \\
\text { TCGTATGGAACGATGTGATGA }\end{array}$ & $56^{\circ} \mathrm{C}$ & 140 & 4982046 & 1 & [21] \\
\hline \multicolumn{9}{|c|}{$R f_{4}$ Locus } \\
\hline 3 & SSR & DRCG-RF4-8 & $\begin{array}{c}\text { F-TGGGATCATGAAAGCCATAC } \\
\text { R-GCTTTATAGGCGCCGATTTT }\end{array}$ & $57^{\circ} \mathrm{C}$ & 845 & 18211995 & 10 & [21] \\
\hline 4 & SSR & RM 6100 & $\begin{array}{l}\text { F- TCCTCTACCAGTACCGCACC } \\
\text { R- GCTGGATCACAGATCATTGC }\end{array}$ & $58^{\circ} \mathrm{C}$ & 160 & $1.2 \mathrm{cM}$ & 10 & [22] \\
\hline
\end{tabular}




\subsection{PCR Amplification}

DNAs were extracted from the plants belonging to the parents and back-cross generations employing the simplified mini-scale method [23]. PCR reactions $(15 \mu \mathrm{L})$ containing $3 \mu \mathrm{L}$ of genomic DNA, $1 \times$ assay buffer, $200 \mu \mathrm{L}$ of dNTPs, $2 \mu \mathrm{M} \mathrm{MgCl}_{2}, 0.2 \mu \mathrm{M}$ each primer (forward and reverse), and 1 unit of Taq polymerase (Bangalore Genei) were amplified. The temperature cycle was programmed as $95^{\circ} \mathrm{C}$ for $2 \mathrm{~min}, 94{ }^{\circ} \mathrm{C}$ for $45 \mathrm{~s}, 52^{\circ} \mathrm{C}$ for $1 \mathrm{~min}, 72{ }^{\circ} \mathrm{C}$ for $1.30 \mathrm{~min}$ for $35 \mathrm{cycles}$, and an additional temperature of $72{ }^{\circ} \mathrm{C}$ for $10 \mathrm{~min}$ for extension and $4{ }^{\circ} \mathrm{C}$ for cooling. The amplified products were electrophoresed in a $3 \%$ agarose gel and stained with ethidium bromide. Clearly resolved, unambiguous bands were scored visually for their presence with each primer.

Closely linked fertility restoration markers, i.e., RM 6100 and DRCG-RF4-8 for Rf4 locus and DRRM-RF3-10 for $R f 3$ locus, were used to identify the plants with restorer alleles in $\mathrm{BC}_{3} \mathrm{~F}_{2}$ generation.

\subsection{Screening for Blast Resistance, Pollen Fertility, and Evaluation of Agronomic Characters in Improved Lines}

The back-cross-derived lines $\left(\mathrm{BC}_{3} \mathrm{~F}_{3}\right)$ along with parents and IR 24 (susceptible check) and Tetep (resistant check) were screened for blast resistance under a uniform blast nursery (UBN) using a virulent local isolate IS (KUL)- 6 of $M$. oryzae [24]. For UBN screening, each $\mathrm{BC}_{3} \mathrm{~F}_{3}$ line was sown in a single row 50 long and $10 \mathrm{~cm}$ apart, and after every 20 test entries and border rows of all the sides of bed the susceptible check IR 24 was planted. This helps to spread the inoculum. Relative humidity is maintained with water sprinklers. The beds were covered during the night to maintain a high humidity until disease development. Additionally, to create severe incidence across the bed, seven-day-old fungal culture maintained as described by Srinivas Prasad et al. [25] was used for artificial inoculation. The adjusted spore concentration of $10^{5}$ spores $/ \mathrm{mL}$ [2] was sprayed over the entire UBN plot until the entire plant surface of each individual plant become wet. On the fifteenth day after inoculation, the lines were scored for their resistance reaction as per IRRI (International Rice Research Institute) standard evaluation system using the 0-9 disease severity scale (IRRI 1996).

Pollen fertility was estimated from $\mathrm{BC}_{3} \mathrm{~F}_{3}$ lines by using $1 \%$ potassium iodide solution (Supplementary Figure S1). Plants with round and deeply stained pollen grains were classified as fertile. To evaluate the important agronomic traits, twenty-five-day-old seedlings of improved lines along with parents and checks were raised in experimental plot at the Agricultural College and Research Institute, Tamil Nadu Agricultural University, Madurai, India. The experimental plot was arranged in a randomized block design with three replications following standard agronomic practices [26,27]. Each improved line was raised in three rows, each row containing 20 plants. Ten plants in each replication were monitored for the observation of major yield contributing traits. Agronomic traits including days for $50 \%$ flowering, plant height $(\mathrm{cm})$, number of productive tillers per plant, panicle length $(\mathrm{cm})$, number of filled grains, 100-grain weight $(\mathrm{g})$, and grain yield per plant $(\mathrm{g})$ were recorded.

\subsection{Statistical Analysis}

The segregation pattern of Pi54 gene was calculated using the chi-square test $\left(\chi^{2}\right)$ with the formulae $\chi^{2}=(\mathrm{O}-\mathrm{E})^{2} / \mathrm{E}$, where $\mathrm{O}$ represents the observed frequency and $\mathrm{E}$ represents the expected frequency. The SAS (Statistical Analysis System) package (SAS Institute Inc., Cary, NC, USA) was used for the analysis of the significance of variation between parents and improved restorer lines. The agglomerative clustering among the selected pyramided lines and parents was calculated based on seven quantitative traits using " $R$ " software $(R, 2013)$.

\section{Results}

The $\mathrm{F}_{1}$ plants in two crosses were confirmed for their heterozygous nature using the functional marker, Pi54 MAS. Heterozygous plants were back-crossed to respective recurrent parents (CB $87 \mathrm{R}$ and $C B 174 R$ ) to develop $B_{1} F_{1}$. In $B_{1} F_{1}$ generation, a total of 21/183 (Imp. CB $87 \mathrm{R}$ ) and 17/194 
(Imp. CB $174 \mathrm{R}$ ) plants showed heterozygosity for the marker, Pi54 MAS, which was linked to the blast resistance gene. The positive $\mathrm{BC}_{1} \mathrm{~F}_{1}$ plants were subjected to background selection using 70 polymorphic markers (https://archive.gramene.org/markers/microsat/ssr.html) to identify the plants with maximum recurrent parent genome $\left(\mathrm{R}_{\mathrm{PG}} \mathrm{R}\right)$. The heterozygous plants with a maximum parental genome of $73.6 \%(C B 87 \mathrm{R})$ and $74.9 \%(\mathrm{CB} 174 \mathrm{R})$ were selected and back-crossed to generate $\mathrm{BC}_{2} \mathrm{~F}_{1}$ plants. Back-crosses were continued up to $\mathrm{BC}_{3}$ to recover the maximum recurrent genome. Positive $\mathrm{BC}_{3} \mathrm{~F}_{1}$ plants with the maximum recurrent genome of $91.1 \%$ in $\mathrm{CB} 87 \mathrm{R}$ and $90.3 \%$ were self-pollinated to produce $\mathrm{BC}_{3} \mathrm{~F}_{2}$ plants. A total of 41 homozygous plants in $\mathrm{CB} 87 \mathrm{R}$ and 46 in $\mathrm{CB} 174 \mathrm{R}$ for the Pi54 MAS marker were screened for fertility restoring genes ( $R f 3$ and $R f 4$ ) using gene specific/linked markers; DRRM-RF3-5 for Rf3 and DRCG-RF4-8 \& RM 6100 for Rf4. Nine (CB 87 R) and 13 (CB 174 R) plants showing the co-segregating banding pattern in $\mathrm{BC}_{3} \mathrm{~F}_{3}$ (Figure 2) were subjected to the pollen fertility study and agronomic traits. The number of plants scored for both blasts and fertility restoration using gene-specific markers in different back-crosses generation is provided in Supplementary Table S2. The segregation pattern of blast resistance in $\mathrm{BC}_{3} \mathrm{~F}_{2}$ generation plants was tested using $\chi^{2}$ statistics. In the CB $87 \mathrm{R} \times \mathrm{B} 95$ cross, the observed segregating frequency was 41:106:63, while in the other cross, $\mathrm{CB} 174 \mathrm{R} \times \mathrm{B} 95$, it was about 46:127:87. Collectively, in both the crosses, the $\chi^{2}$ value was non-significant and hence the observed genotypic ratio was nearly equal to the expected genotypic ratio (Table 2).

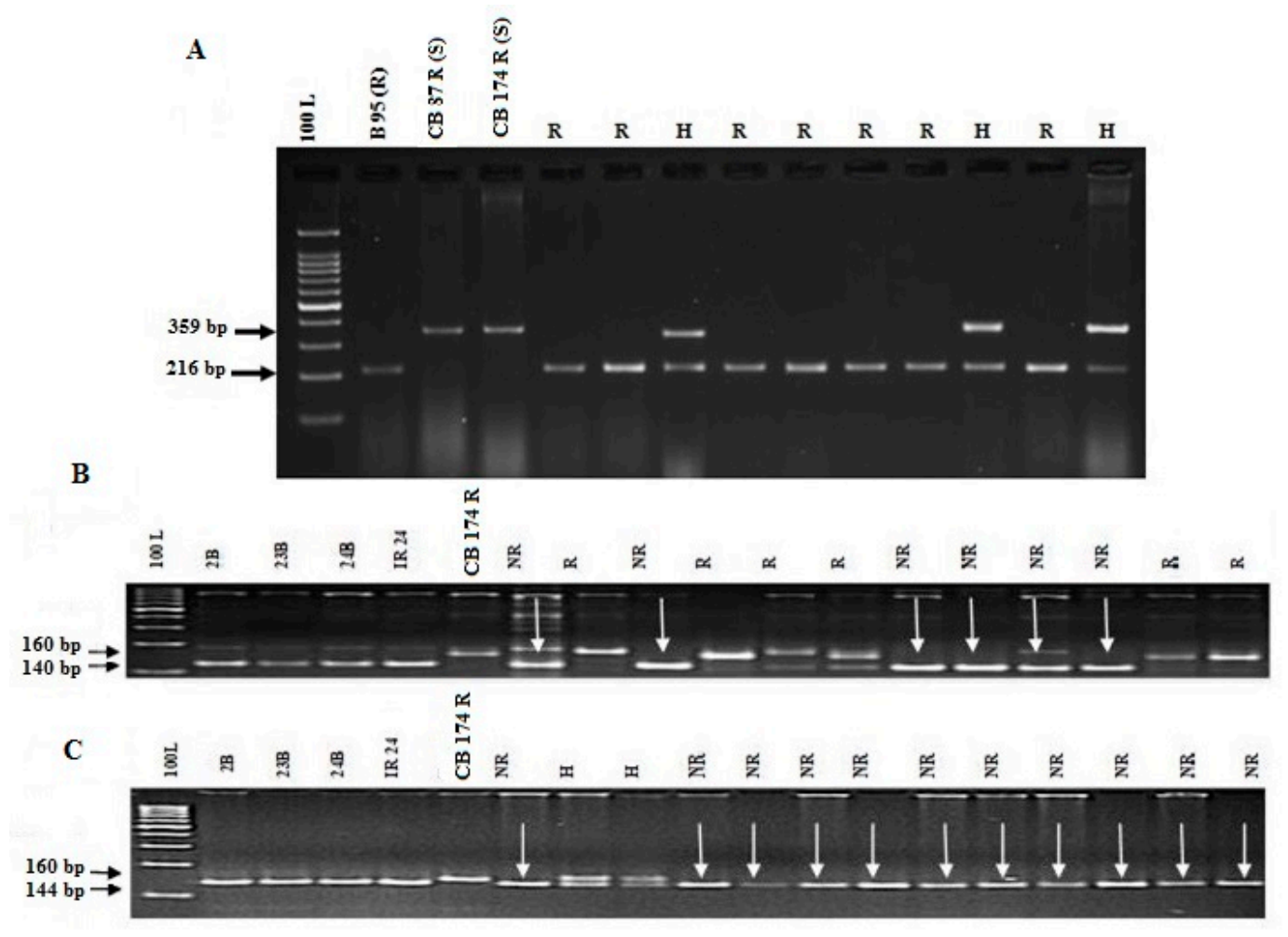

Figure 2. Foreground selection in progenies. $\mathrm{PCR}$ amplification of $\mathrm{BC}_{3} \mathrm{~F}_{2}$ plants in $\mathrm{CB} 87 \mathrm{R} \times$ Tetep cross. (A) Pi54 MAS, primer for Pi54 blast resistance gene. (B) DRRM-RF3-10, marker for $R f 3$ gene. (C) RM 6100 marker for Rf4 gene. 100 L, 100 bp ladder; R, resistant; $\mathrm{H}$, heterozygote; S, susceptible; $\mathrm{NR}$, non- restorer; R, restorer. B 95 is the blast resistance line; CB $87 \mathrm{R}, \mathrm{CB} 174 \mathrm{R}$ are susceptible lines; 2B, 23B, 24 B, IR 24 are non-restorer genotypes; CB 87 R, CB $174 \mathrm{R}$ are restorer genotypes. 
Table 2. Segregating ratio of the marker genotypes in $\mathrm{BC}_{3} \mathrm{~F}_{2}$ generation for Pi54 blast resistance gene.

\begin{tabular}{cccccccccccc}
\hline S.No & & \multicolumn{4}{c}{ CB 87 R $\times$ B 95 } & \multicolumn{4}{c}{ CB 174 R $\times$ B 95 } \\
\hline & Markers & \multicolumn{4}{c}{ Observed Frequency } & \multicolumn{4}{c}{ Observed Frequency } \\
\hline & & RR & Rr & rr & Total & $\chi^{\mathbf{2}} \mathbf{( 1 : 2 : 1 )}$ & RR & Rr & rr & Total & $\chi^{\mathbf{2}} \mathbf{( 1 : 2 : 1 )}$ \\
\hline 1 & Pi54 MAS & 41 & 106 & 63 & 210 & 1.504 & 46 & 127 & 87 & 260 & 1.487 \\
\hline \multicolumn{4}{c}{ RR, rr, Homozygotes; Rr, Heterozygote. } &
\end{tabular}

\subsection{Assessment of Blast Resistance in the Pi54 Gene-Introgressed Lines}

Twenty-two three-gene homozygous back-cross-derived lines were included for blast screening in the cross combination, along with recurrent parents, donor, and positive (Tetep) and negative check (IR 24). The disease susceptibility was evaluated for blast pathogen under controlled artificial greenhouse environment. The donor parent, B 95, and positive check, Tetep, harboring the Pi54 gene, showed a high level of resistance to rice blasts (Figure 3) and scored as "1", whereas, CB $87 \mathrm{R}$ and CB174 R showed susceptibility to rice blasts and were scored as "9". The twenty-two advanced three-gene (Pi54 + Rf3 + Rf4) homozygous-introgressed lines viz. Imp. CB $87 \mathrm{R}$ (9 lines) and Imp. CB $174 \mathrm{R}$ (13 lines) were selected from both of the parental crosses. The developed lines with the blast resistance gene exhibited no lesions on leaves and received a representative score of " $0-2$ ". The improved lines with two-gene combinations (Pi54 + Rf3 E Pi54 + Rf4) were excluded from our analysis. The blast resistance scoring and pollen fertility status for the improved lines and parents is presented in Table 3. The donor parent, B 95 (B 95-1 × Tetep) with the Pi54 gene, was found to be resistant to the virulent isolate of the pathogen (IS (KUL)-6) which is more prevalent in South India. At the time of the disease evaluation, each of the improved lines exhibited no symptoms and thus scored as "1". Roundish-shaped, small gray spots, slightly enlarged (1-2 $\mathrm{mm}$ in diameter) with a brown margin, present on the lower leaves were scored as " 2 ". High pollen fertility was observed in all the improved lines (Supplementary Figure S1)
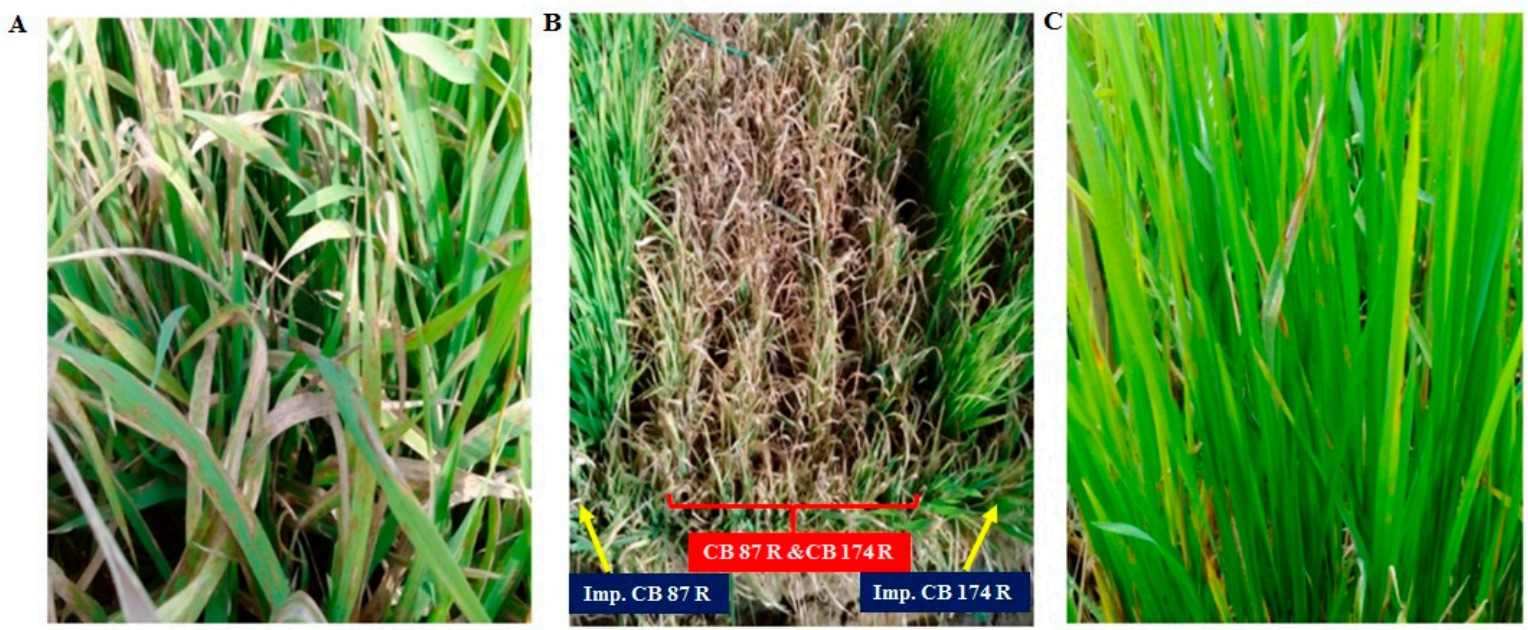

Figure 3. Phenotypic screening for blast resistance. Magnaporthe oryzae-infected plants (post-inoculation view). (A) Negative check, IR 24. (B) Unimproved and improved restorer lines of CB $87 \mathrm{R}$ and CB 174 R. (C) Positive check, Tetep. 
Table 3. Disease screening and fertility status of three-gene positive $\mathrm{BC}_{3} \mathrm{~F}_{3}$ improved lines for resistance to blast disease.

\begin{tabular}{|c|c|c|c|c|c|c|}
\hline \multirow[b]{2}{*}{ S. No } & \multirow[b]{2}{*}{ Pyramided Lines } & \multirow[b]{2}{*}{$\begin{array}{l}\text { Allelic Status } \\
\text { (Pi54, Rf3, Rf4) }\end{array}$} & \multirow{2}{*}{$\begin{array}{l}\text { Resistance } \\
\text { Genes } \\
\text { Genotyped by } \\
\text { Linked Marker }\end{array}$} & \multicolumn{2}{|c|}{ Reaction Against to Blast } & \multirow{2}{*}{$\begin{array}{c}\text { Pollen } \\
\text { Fertility } \\
\text { Status (\%) }\end{array}$} \\
\hline & & & & $\begin{array}{c}* \text { Disease } \\
\text { Scoring for Rice } \\
\text { Blast (0-9 scale) }\end{array}$ & $\mathrm{R} / \mathrm{S}$ & \\
\hline \multicolumn{7}{|c|}{ CB $87 \mathrm{R} \times$ B 95-Improved CB $87 \mathrm{R}$} \\
\hline 1 & $5-3-7-1$ & $P i 54+R f 3+R f 4$ & ++ & 1 & $\mathrm{R}$ & 92.1 \\
\hline 2 & $5-3-7-3$ & $P i 54+R f 3+R f 4$ & ++ & 1 & $\mathrm{R}$ & 92.8 \\
\hline 3 & $5-3-7-4$ & $P i 54+R f 3+R f 4$ & ++ & 0 & $\mathrm{R}$ & 92.3 \\
\hline 4 & $5-3-7-5$ & $P i 54+R f 3+R f 4$ & ++ & 2 & $\mathrm{R}$ & 82.6 \\
\hline 5 & $5-3-7-6$ & $P i 54+R f 3+R f 4$ & ++ & 1 & $\mathrm{R}$ & 91.2 \\
\hline 6 & $5-3-7-8$ & $P i 54+R f 3+R f 4$ & ++ & 1 & $\mathrm{R}$ & 82.3 \\
\hline 7 & $5-3-7-9$ & $P i 54+R f 3+R f 4$ & ++ & 2 & $\mathrm{R}$ & 80.1 \\
\hline 8 & $5-3-7-10$ & $P i 54+R f 3+R f 4$ & ++ & 2 & $\mathrm{R}$ & 93.8 \\
\hline 9 & $5-3-7-12$ & $P i 54+R f 3+R f 4$ & ++ & 1 & $\mathrm{R}$ & 91.7 \\
\hline \multicolumn{7}{|c|}{ CB 174 R × B 95-Improved CB 174 R } \\
\hline 10 & $5-3-8-1$ & $P i 54+R f 3+R f 4$ & ++ & 1 & $\mathrm{R}$ & 81.1 \\
\hline 11 & $5-3-8-2$ & $P i 54+R f 3+R f 4$ & ++ & 2 & $\mathrm{R}$ & 90.8 \\
\hline 12 & $5-3-8-4$ & $P i 54+R f 3+R f 4$ & ++ & 0 & $\mathrm{R}$ & 80.4 \\
\hline 13 & $5-3-8-6$ & $P i 54+R f 3+R f 4$ & ++ & 1 & $\mathrm{R}$ & 81.7 \\
\hline 14 & $5-3-8-7$ & $P i 54+R f 3+R f 4$ & ++ & 2 & $\mathrm{R}$ & 91.6 \\
\hline 15 & $5-3-8-8$ & $P i 54+R f 3+R f 4$ & ++ & 2 & $\mathrm{R}$ & 83.9 \\
\hline 16 & $5-3-8-10$ & $P i 54+R f 3+R f 4$ & ++ & 2 & $\mathrm{R}$ & 93.8 \\
\hline 17 & $5-3-8-11$ & $P i 54+R f 3+R f 4$ & ++ & 0 & $\mathrm{R}$ & 91.2 \\
\hline 18 & $5-3-8-15$ & $P i 54+R f 3+R f 4$ & ++ & 1 & $\mathrm{R}$ & 81.4 \\
\hline 19 & $5-3-8-16$ & $P i 54+R f 3+R f 4$ & ++ & 1 & $\mathrm{R}$ & 88.9 \\
\hline 20 & $5-3-8-17$ & $P i 54+R f 3+R f 4$ & ++ & 1 & $\mathrm{R}$ & 91.2 \\
\hline 21 & $5-3-8-19$ & $P i 54+R f 3+R f 4$ & ++ & 1 & $\mathrm{R}$ & 90.3 \\
\hline 22 & $5-3-8-22$ & $P i 54+R f 3+R f 4$ & ++ & 1 & $\mathrm{R}$ & 80.9 \\
\hline 23 & $\begin{array}{c}\text { IR } 24 \\
\text { (Negative check) }\end{array}$ & & -- & 9 & $S$ & \\
\hline 24 & $\begin{array}{c}\text { CB 87 R } \\
\text { (Recurrent parent) }\end{array}$ & $R f 3+R f 4$ & -- & 9 & $\mathrm{~S}$ & 95.6 \\
\hline 25 & $\begin{array}{c}\text { CB 174 R } \\
\text { (Recurrent parent) }\end{array}$ & $R f 3+R f 4$ & -- & 9 & $\mathrm{~S}$ & 92.9 \\
\hline 26 & $\begin{array}{c}\text { B } 95 \\
\text { (Donor parent) }\end{array}$ & Pi54 & ++ & 1 & $\mathrm{R}$ & \\
\hline 27 & $\begin{array}{c}\text { Tetep } \\
\text { (positive check) }\end{array}$ & Pi54 & ++ & 1 & $\mathrm{R}$ & - \\
\hline
\end{tabular}

* The back-cross-derived lines at $\mathrm{BC}_{3} \mathrm{~F}_{3}(P i 54+R f 3+R f 4)$ three-line pyramided lines were screened with a blast isolate under controlled conditions using the UBN method. "+" and "-" indicates positive and negative alleles.

\subsection{Agronomic Traits in Improved Restorer Lines}

The twenty-two three-positive $\mathrm{BC}_{3} \mathrm{~F}_{3}$ plants, along with the parents of both crosses, were screened for agronomic performance parameters. The three-gene pyramided lines 5-3-7-6 and 5-3-8-10, although phenotypically similar to recurrent parents, performed better for most of the agronomic traits studied (Table 4, Supplementary Table S3 and Figure S2). Interestingly, some of the improved lines had earlier maturity (8 days) compared to CB 87 R and CB 174 R. Five out of 22 improved lines possessed increased productive tillers, number of filled grains, and hundred grain weight as compared to recurrent parents. None of the improved lines displayed significant variation for plant height, panicle length, and grain yield compared to the unimproved restorer lines. 
Table 4. Agronomic characters of improved restorer lines.

\begin{tabular}{|c|c|c|c|c|c|c|c|c|}
\hline S.No & Plant No. & $\begin{array}{l}\text { Days to } \\
\text { Flowering }\end{array}$ & $\begin{array}{c}\text { Plant } \\
\text { Height } \\
\text { (cm) }\end{array}$ & $\begin{array}{c}\text { No. } \\
\text { Productive } \\
\text { Tillers }\end{array}$ & $\begin{array}{c}\text { Panicle } \\
\text { Length } \\
\text { (cm) }\end{array}$ & $\begin{array}{c}\text { No. } \\
\text { Filled } \\
\text { Grains }\end{array}$ & $\begin{array}{l}100 \text { Grain } \\
\text { Weight (g) }\end{array}$ & $\begin{array}{l}\text { Grain } \\
\text { Yield (g) }\end{array}$ \\
\hline 1 & $5-3-7-1$ & $73.9^{1}$ & 78.2 & 13.5 & 22.7 & 124.9 & $2.17^{1}$ & 24.17 \\
\hline 2 & $5-3-7-3$ & $72.3^{1}$ & 73.5 & 12.8 & 21.6 & 116.7 & 1.83 & 22.87 \\
\hline 3 & $5-3-7-4$ & $73.2^{1}$ & 76.8 & 13.7 & 20.8 & 118.5 & $2.07^{1}$ & 19.43 \\
\hline 4 & $5-3-7-5$ & $71.5^{1}$ & 84.9 & 11.5 & 23.3 & $138.3^{1}$ & $2.17^{1}$ & 22.30 \\
\hline 5 & $5-3-7-6$ & 77.1 & 84.4 & $15.8^{1}$ & 23.1 & 123.0 & 1.77 & 27.07 \\
\hline 6 & $5-3-7-8$ & $71.8^{1}$ & 78.1 & 14.4 & 20.8 & 109.8 & 1.73 & 21.43 \\
\hline 7 & $5-3-7-9$ & $68.6^{1}$ & 68.6 & $15.2^{1}$ & 18.7 & 128.6 & $2.13^{1}$ & 18.73 \\
\hline 8 & $5-3-7-10$ & $71.7^{1}$ & 77.3 & 13.1 & 22.0 & 128.6 & $2.30^{1}$ & 21.23 \\
\hline 9 & $5-3-7-12$ & 75.6 & 85.5 & $14.9^{1}$ & 21.2 & 123.2 & $2.03^{1}$ & 20.17 \\
\hline 10 & $5-3-8-1$ & $73.2^{2}$ & 75.5 & 13.4 & 22.7 & 110.5 & 2.17 & 22.30 \\
\hline 11 & $5-3-8-2$ & $69.1^{2}$ & 89.1 & 13.8 & 18.6 & $125.6^{2}$ & 2.27 & 19.07 \\
\hline 12 & $5-3-8-4$ & $74.7^{2}$ & 74.7 & $14.7^{2}$ & 15.2 & 115.0 & 2.13 & 20.87 \\
\hline 13 & $5-3-8-6$ & 78.7 & 96.3 & 13.3 & 18.4 & 117.7 & 2.23 & 18.47 \\
\hline 14 & $5-3-8-7$ & $71.6^{2}$ & 77.0 & 13.3 & 22.2 & $123.6^{2}$ & 1.83 & 21.77 \\
\hline 15 & $5-3-8-8$ & $75.2^{2}$ & 75.4 & 13.6 & 18.8 & 116.1 & 2.07 & 19.17 \\
\hline 16 & $5-3-8-10$ & 77.5 & 95.8 & $16.0^{2}$ & 24.1 & $126.8^{2}$ & 2.40 & 26.40 \\
\hline 17 & $5-3-8-11$ & $72.7^{2}$ & 85.8 & 13.0 & 17.3 & $125.6^{2}$ & 2.13 & 19.60 \\
\hline 18 & $5-3-8-15$ & $72.2^{2}$ & 84.6 & 12.2 & 19.0 & 116.9 & 2.03 & 20.13 \\
\hline 19 & $5-3-8-16$ & $71.8^{2}$ & 81.8 & 11.3 & 21.6 & 117.5 & 1.97 & 21.30 \\
\hline 20 & $5-3-8-17$ & 76.2 & 83.9 & 12.3 & 16.1 & 112.7 & 1.73 & 19.63 \\
\hline 21 & $5-3-8-19$ & $71.2^{2}$ & 76.0 & 12.4 & 21.2 & 120.9 & 1.97 & 21.73 \\
\hline 22 & $5-3-8-22$ & $73.3^{2}$ & 76.7 & 13.2 & 22.1 & 109.3 & 2.17 & 20.83 \\
\hline 23 & IR 24 & 83.3 & 86.0 & 13.3 & 24.0 & 119.3 & 2.33 & 29.17 \\
\hline 24 & CB $87 \mathrm{R}$ & 76.8 & 86.8 & 13.2 & 22.9 & 127.5 & 1.83 & 27.90 \\
\hline 25 & CB174 R & 77.2 & 95.5 & 12.6 & 23.4 & 115.5 & 2.50 & 26.03 \\
\hline \multirow[t]{4}{*}{26} & В 95 & 77.4 & 114.3 & 12.4 & 22.9 & 98.3 & 2.13 & 25.60 \\
\hline & Mean \pm 2SE & 73.11 & 85.78 & 14.35 & 21.97 & 124.75 & 3.40 & 23.46 \\
\hline & $\mathrm{CV} \%$ & 1.16 & 2.68 & 6.16 & 4.42 & 3.73 & 3.60 & 4.89 \\
\hline & LSD & 1.4 & 3.7 & 1.4 & 1.5 & 7.3 & 0.58 & 1.78 \\
\hline
\end{tabular}

${ }^{1}$ Increased over CB 87 R, ${ }^{2}$ increased over CB 174 R; IR 24 susceptible check, CB 87 R, CB 174 R recurrent parents, B 95 donor parent; $\mathrm{CV}$, coefficient of variation; LSD, critical difference at $5 \%$ probability level; values are mean of three replications.

\subsection{Cluster Analysis}

Agglomerative clustering with Euclidean values divided the improved restorer lines and parents into four clusters (cophenetic correlation coefficient $=0.716$ ). Cluster one consisted of three parents and two improved lines, while cluster two had the donor parent alone. Cluster three had six improved lines and cluster four had fourteen improved lines (Supplementary Figure S3). The highest yielding improved lines were placed in cluster one and found very similar to both recurrent parents.

\section{Discussion}

The present study was carried out with the objective to introgress a blast resistant gene, Pi54, into the background of popular restorer lines, CB $87 \mathrm{R}$ and CB $174 \mathrm{R}$, through marker-assisted back-cross breeding coupled with screening for improved agronomic traits. Improvement of these lines for blast disease resistance facilitates the development of new generation of hybrids with durable resistance against blast disease in addition to bacterial blight disease. Since the 1960s, more than 100 resistance genes or loci for blast disease have been identified [28,29]. Among them, the majority of the genes have been induced by pathogen infection, while a few of the genes express constitutively. In addition, the expression of many $R$ genes induce resistance against leaf blast at the seedling stage, while only a few $R$ genes confer resistance to panicle blast [30-33]. Such complex interactions of $R$ genes are an important challenge in blast resistance breeding to achieve broad-spectrum and durable resistance. Earlier reports on pyramiding of $P i$ genes against blast disease in different background 
combinations (indica, japonica) indicated the expression of varying levels of resistance. This means that different gene combinations produce different interaction effects, and some show no resistance comprising the simple accumulation of the resistance spectra of the target $\mathrm{R}$ genes [34-37]. However, the blast-resistant gene, Pi54, which was identified in a highly resistant genotype, Tetep, was confirmed to have broad-spectrum resistance against predominant races found in India [2,13]. The Pi54, from the Piz locus, also shows broad-spectrum resistance to both leaf and panicle blasts [12]. Wu et al. [37] also reported that pyramiding of Pi54 along with Pi1, Pi33, and Pigm exhibited high level of resistance to leaf and panicle blasts. Similarly, it was also proved that the R genes of the alleles from the Piz locus exhibit excellent resistance after combining them with certain independently distributed $\mathrm{R}$ genes, such as Pi56 and Pish [38]. To date, many successful marker-assisted introgression using the Pi54 gene have been made in the various backgrounds of rice varieties and hybrids all over the world [2,36,39-41]. Keeping in view with this, the present study aimed to introgress the Pi54 gene from Tetep into stable restorer lines CB $87 \mathrm{R}$ and CB $174 \mathrm{R}$, but susceptible to blast disease through MABB. To the best of our knowledge, ours is the third such report wherein functional marker Pi54 MAS has been utilized for foreground selection. Earlier, Vijay Kumar et al. [1] successfully introgressed the Pi54 gene from a highly blast-resistant genotype, i.e., Tetep, into an elite rice cultivar Samba Mahsuri (BPT 5204), a high-yielding rice variety with good cooking quality, but susceptible to blast disease, through MABB. Subsequently, a Samba Mahsuri variety, JGL1798, was introgressed with the Pi54 gene to resist against blast disease along with BB resistance through functional marker Pi54 MAS [42]. Therefore, pyramiding the alleles of Pi54 along with BB-harboring stable restorer lines would greatly accelerate the hybrid rice program for durable resistance against important biotic stresses of rice.

For foreground selection, the functional marker, Pi54 MAS specific to the Pi54 gene, was used to identify the plants carrying heterozygous alleles for the targeted resistant gene at each back-cross generation. The Pi54 MAS is an InDel targeting a 144-bp insertion/deletion polymorphism between the resistant and susceptible allelic sequences [21]. In addition, its co-dominant nature perfectly co-segregates the blast resistance gene in a 1:2:1 ratio in the segregating mapping population. Earlier, studies also proved that the Pi54 MAS has an accurate genotyping ability ( $>98 \%$ ) and predicts the allelic status efficiently in many rice cultivars, and it is routinely used in the many MABB programs $[12,21,43]$ globally. For background analysis, 156 SSR markers distributed across the rice genome were employed to analyze the recovery of recurrent parent genome (RPG) in both improved lines. The stringent phenotypic and background selection from $\mathrm{BC}_{1}, \mathrm{BC}_{2}$, and $\mathrm{BC}_{3}$ populations recovered 90.3 to $91.1 \%$ recurrent parent genomes at $\mathrm{BC}_{3} \mathrm{~F}_{3}$ generation of both populations. While improving the restorer line for blast resistance, it is absolutely necessary that the back-cross-derived lines should also possess the fertility-restorer genes, $R f 3$ and $R f 4$. Closely linked gene-specific markers, DRRM-RF3-10, DRCG-RF4-8, and RM6100, were used for the identification of fertility restoration genes $R f 3$ and $R f 4$ along with target gene (Pi54) in the segregating population.

In this study, we used a higher number of parental polymorphic markers with a better coverage per chromosome for genetic background selection. This has certainly resulted in limiting the linkage drag to the regions closer to the target genes [44]. Through stringent phenotypic and background selection at each back-cross generation, we have identified intercrossed lines with increased productive tillers, grain filling, and 100-grain weight than the recurrent parent. This indicates that utilization of the improved blast-resistant restorer lines in the hybridization program would be of great advantage currently and in the future.

Our research group has previously released two rice hybrids, CO RH3 and CO RH4, utilizing the restorers, CB $87 \mathrm{R}$ and CB $174 \mathrm{R}$ [45]. These hybrids played a significant role in improving the rice production from 2010 onwards at both the regional and national level. On the contrary, there were continuous complaints from the farmers about susceptibility of the above hybrids to the blast disease. Earlier, we improved three popular cytoplasmic male sterile lines, CO 2A, CO 23A, and CO 23B, for bacterial blight resistance through functional markers and developed stable hybrids with high yield and BB resistance [19]. Our improved lines, especially 5-3-7-6 and 5-3-8-10 with the Pi54 
gene, and similar phenotypic characters of restorer lines have brought back the full genetic potential and yield of two hybrids, CO RH3 and CO RH4. In addition, the improved restorer lines and already improved cytoplasmic male sterile lines will be useful in the development of new blast and bacterial blight-resistant hybrids in the near future.

In conclusion, MABB breeding techniques are much effective than conventional breeding, which helps in the quicker and maximum recovery of genetic backgrounds along with target genes with minimum linkage drag. We successfully introgressed a single dominant blast resistance gene, Pi54, in the susceptible restorer rice lines viz. CB 87 R and CB $174 \mathrm{R}$, along with the two fertility-restorer genes Rf3 and Rf4. The introgression of Pi54 remarkably increased the blast resistance level and maintained the yield levels in blast endemic regions. The breakdown of resistance is a natural phenomenon and the only alternative is to introgress the various allelic forms of Pi54 in a single genetic background. We expect that the improved lines will provide blast resistance at least for a foreseeable period in Southern India. Meanwhile, our Pi54 allelic pyramided restorer lines will be ready for long-term use in hybrid rice production.

Supplementary Materials: The following are available online at http://www.mdpi.com/2073-4425/11/11/1266/s1, Table S1: List of microsatellite markers polymorphic between donor parent B 95 and recurrent parents CB $87 \mathrm{R}$ and CB 174 R lines. (Marker source: https://archive.gramene.org/markers/microsat/ssr.html), Table S2: Details of blast resistance (Pi54), fertility restorer genes (Rf3, Rf4) in backcross generation, Table S3: Analysis of Variance for agronomic performance of pyramided lines, Figure S1: Pollen fertility studies on $\mathrm{BC}_{3} \mathrm{~F}_{3}$ plants. (A) Sterile. (B) Partial fertile /sterile. (C) Fertile, Figure S2: Distribution of parents (CB 87 R and CB 174 R) and improved genotypes means for blast response. Tetep and IR 24 are the positive and negative check respectively. B 95 is the donor parent, Figure S3: Agglomerative clustering method based on seven quantitative characters in pyramided lines.

Author Contributions: J.R., R.S., and A.R. initiated the project, and made a substantial, direct, intellectual contribution to the work. S.P., G.A., and V.G.R. performed the experiments. All the authors reviewed the final version of the manuscript. All authors have read and agreed to the published version of the manuscript.

Funding: This study was financially supported by UGC under a major research grant (41-1224/2012 [SR]), New Delhi, India.

Acknowledgments: This study was financially supported by UGC under a major research grant, New Delhi, India. The author J.R. acknowledges UGC for providing assistance for research program at Tamil Nadu Agricultural University, Coimbatore, part of which is reported in this study. The authors would like to extend their sincere appreciation to Tamil Nadu Agricultural University, Coimbatore, Tamil Nadu and India.

Conflicts of Interest: The authors declare that the research was conducted in the absence of any commercial or financial relationships that could be construed as a potential conflict of interest.

\section{References}

1. Vijay Kumar, S.; Rambabu, R.; Bhaskar, B.; Madhavi, K.R.; Srikanth, S.; Prakasam, V.; Sundaram, R.M.; Sheshu Madhav, M.; Subba Rao, L.V.; Prasad, M.S. Introgression of durable blast resistance gene Pi-54 into indica rice cv. samba Mahsuri, through Marker Assisted Backcross Breeding. Electron. J. Plant. Breed. 2018, 9, 705-715. [CrossRef]

2. Tanweer, F.A.; Rafii, M.Y.; Sijam, K.; Rahim, H.A.; Ahmed, F.; Latif, M.A. Current advance methods for the identification of blast resistance genes in rice. C. R. Biol. 2015, 338. [CrossRef] [PubMed]

3. Mackill, D.J.; Bonman, J.M. Inheritance of Blast Resistance in Near-Isogenic Lines of Rice. Phytopathology 1992, 82. [CrossRef]

4. Dean, R.A.; Talbot, N.J.; Ebbole, D.J.; Farman, M.L.; Mitchell, T.K.; Orbach, M.J.; Thon, M.; Kulkarni, R.; $\mathrm{Xu}$, J.-R.; Pan, H.; et al. The genome sequence of the rice blast fungus Magnaporthe grisea. Nature 2005, 434, 980-986. [CrossRef] [PubMed]

5. Ebbole, D. Magnaporthe as a Model for Understanding Host-Pathogen Interactions. Annu. Rev. Phytopathol. 2007, 45, 437-456. [CrossRef] [PubMed]

6. Skamnioti, P.; Gurr, S. Against the grain: Safeguarding rice from rice blast disease. Trends Biotechnol. 2009, 27, 141-150. [CrossRef]

7. Sharma, T.R.; Rai, A.K.; Gupta, S.K.; Vijayan, J.; Devanna, B.N.; Ray, S. Rice Blast Management Through Host-Plant Resistance: Retrospect and Prospects. Agric. Res. 2012, 1, 37-52. [CrossRef] 
8. Musiime, O.; Tenywa, M.M.; Majaliwa, M.J.G.; Lufafa, A.; Nanfumba, D.; Wasige, J.E.; Woomer, P.L.; Kyondha, M. Constraints to rice production in Bugiri District. Afr. Crop. Sci. Conf. Proc. 2005, 7, 1495-1499.

9. Srinivasan, B.; Gnanamanickam, S.S. Identification of a new source of resistance in wild rice, Oryza rufipogon to bacterial blight of rice caused by Indian strains of Xanthomonas oryzae pv. oryzae. Curr. Sci. 2005, 88, 1229-1231.

10. Khush, G.S.; Jena, K.K. Advances in Genetics, Genomics and Control of Rice Blast Disease. Adv. Genet. Genomics Control. Rice Blast Dis. 2009, 1-10. [CrossRef]

11. Araujo, L.; Soares, J.M.; de Filippi, M.C.C.; Rodrigues, F.Á. Cytological aspects of incompatible and compatible interactions between rice, wheat and the blast pathogen Pyricularia oryzae. Sci. Agric. 2016, 73, 177-183. [CrossRef]

12. Ning, X.; Yunyu, W.; Aihong, L. Strategy for Use of Rice Blast Resistance Genes in Rice Molecular Breeding. Rice Sci. 2020, 27, 263-277. [CrossRef]

13. Sharma, T.R.; Rai, A.K.; Gupta, S.K.; Singh, N.K. Broad-spectrum Blast Resistance Gene Pi-kh Cloned from Rice Line Tetep Designated as Pi54. J. Plant. Biochem. Biotechnol. 2010, 19, 87-89. [CrossRef]

14. Rai, A.; Kumar, S.; Gupta, S.; Gautam, N.; Singh, N.; Sharma, T. Functional complementation of rice blast resistance gene Pik h (Pi54) conferring resistance to diverse strains of Magnaporthe oryzae. J. Plant. Biochem. Biotechnol. 2011, 20, 55-65. [CrossRef]

15. Sharma, T.R.; Madhav, M.S.; Singh, B.K.; Shanker, P.; Jana, T.K.; Dalal, V.; Pandit, A.; Singh, A.; Gaikwad, K.; Upreti, H.C.; et al. High-resolution mapping, cloning and molecular characterization of the Pi-khg ene of rice, which confers resistance to Magnaporthe grisea. Mol. Genet. Genom. 2005, 274, 569-578. [CrossRef] [PubMed]

16. Gupta, S.K.; Rai, A.K.; Kanwar, S.S.; Sharma, T.R. Comparative Analysis of Zinc Finger Proteins Involved in Plant Disease Resistance. PLoS ONE 2012, 7, e42578. [CrossRef]

17. Gupta, S.K.; Rai, A.K.; Kanwar, S.S.; Chand, D.; Singh, N.K.; Sharma, T.R. The single functional blast resistance gene Pi54 activates a complex defence mechanism in rice. J. Exp. Bot. 2011, 63, 757-772. [CrossRef]

18. Devanna, N.B.; Vijayan, J.; Sharma, T.R. The Blast Resistance Gene Pi54of Cloned from Oryza officinalis Interacts with Avr-Pi54 through Its Novel Non-LRR Domains. PLoS ONE 2014, 9, e104840. [CrossRef]

19. Ramalingam, J.; Savitha, P.; Alagarasan, G.; Saraswathi, R.; Chandrababu, R. Functional marker assisted improvement of stable cytoplasmic male sterile lines of rice for bacterial blight resistance. Front. Plant. Sci. 2017, 8, 1-9. [CrossRef]

20. Ramkumar, G.; Srinivasarao, K.; Mohan, K.M.; Sudarshan, I.; Sivaranjani, A.K.P.; Gopalakrishna, K.; Neeraja, C.N.; Balachandran, S.M.; Sundaram, R.M.; Prasad, M.S.; et al. Development and validation of functional marker targeting an InDel in the major rice blast disease resistance gene Pi54 (Pikh). Mol. Breed. 2011, 27, 129-135. [CrossRef]

21. Balaji Suresh, P.; Srikanth, B.; Hemanth Kishore, V.; Subhakara Rao, I.; Vemireddy, L.R.; Dharika, N.; Sundaram, R.M.; Ramesha, M.S.; Sambasiva Rao, K.R.S.; Viraktamath, B.C.; et al. Fine mapping of Rf3 and Rf4 fertility restorer loci of WA-CMS of rice (Oryza sativa L.) and validation of the developed marker system for identification of restorer lines. Euphytica 2012, 187, 421-435. [CrossRef]

22. Sheeba, N.K.; Viraktamath, B.C.; Sivaramakrishnan, S.; Gangashetti, M.G.; Khera, P.; Sundaram, R.M. Validation of molecular markers linked to fertility restorer gene(s) for WA-CMS lines of rice. Euphytica 2009, 167, 217-227. [CrossRef]

23. Zhang, G.; Lu, Y.; Bharaj, T.S.; Virmani, S.S.; Huang, N. Mapping of the Rf-3 nuclear fertility-restoring gene for WA cytoplasmic male sterility in rice using RAPD and RFLP markers. Theor. Appl. Genet. 1997, 94, $27-33$. [CrossRef]

24. Chithrameenal, K.; Ganesh Alagarasan, G.; Raveendran, M.; Robin, S.; Meena, S.; Ramanathan, A.; Ramalingam, J. Genetic enhancement of phosphorus starvation tolerance through marker assisted introgression of OsPSTOL1 gene in rice genotypes harbouring bacterial blight and blast resistance. PLoS ONE 2018, 13, e0204144. [CrossRef]

25. Srivastava, D.; Shamim, M.; Kumar, M.; Mishra, A.; Pandey, P.; Kumar, D.; Yadav, P.; Siddiqui, M.; Singh, K. Current Status of Conventional and Molecular Interventions for Blast Resistance in Rice. Rice Sci. 2017, 25. [CrossRef]

26. Hari, Y.; Srinivasarao, K.; Viraktamath, B.C.; Hari Prasad, A.S.; Laha, G.S.; Ahmed, M.I.; Natarajkumar, P.; Sujatha, K.; Srinivas Prasad, M.; Pandey, M.; et al. Marker-assisted introgression of bacterial blight and blast resistance into IR 58025B, an elite maintainer line of rice. Plant. Breed. 2013, 132, 586-594. [CrossRef] 
27. Abhilash Kumar, V.; Balachiranjeevi, C.H.; Bhaskar Naik, S.B.; Rambabu, R.; Rekha, G.; Harika, G.; Hajira, S.K.; Pranathi, K.; Anila, M.; Kousik, M.; et al. Development of gene-pyramid lines of the elite restorer line, RPHR-1005 possessing durable bacterial blight and blast resistance. Front. Plant. Sci. 2016, 7. [CrossRef]

28. Li, W.; Chern, M.; Yin, J.; Wang, J.; Chen, X. Recent advances in broad-spectrum resistance to the rice blast disease. Curr. Opin. Plant. Biol. 2019, 50, 114-120. [CrossRef]

29. Li, W.; Deng, Y.; Ning, Y.; He, Z.; Wang, G.-L. Exploiting Broad-Spectrum Disease Resistance in Crops: From Molecular Dissection to Breeding. Annu. Rev. Plant. Biol. 2020, 71, 575-603. [CrossRef]

30. Hayashi, N.; Inoue, H.; Kato, T.; Funao, T.; Shirota, M.; Shimizu, T.; Kanamori, H.; Yamane, H.; Hayano-Saito, Y.; Matsumoto, T.; et al. Durable panicle blast-resistance gene Pb1 encodes an atypical CC-NBS-LRR protein and was generated by acquiring a promoter through local genome duplication. Plant. J. 2010, 64, 498-510. [CrossRef]

31. Chen, J.; Shi, Y.; Liu, W.; Chai, R.; Fu, Y.; Zhuang, J.; Wu, J. A Pid3 allele from rice cultivar Gumei2 confers resistance to Magnaporthe oryzae. J. Genet. Genom. 2011, 38, 209-216. [CrossRef] [PubMed]

32. Ma, J.; Chen, J.; Wang, M.; Ren, Y.; Wang, S.; Lei, C.; Cheng, Z. Sodmergen Disruption of OsSEC3A increases the content of salicylic acid and induces plant defense responses in rice. J. Exp. Bot. 2017, 69, 1051-1064. [CrossRef] [PubMed]

33. Cao, N.; Chen, Y.; Ji, Z.J.; Zeng, Y.X.; Yang, C.D.; Liang, Y. Recent progress in molecular mechanism of rice blast resistance. Chin. J. Rice Sci. 2019, 33, 489-498.

34. Hittalmani, S.; Parco, A.; Mew, T.V.; Zeigler, R.S.; Huang, N. Fine mapping and DNA marker-assisted pyramiding of the three major genes for blast resistance in rice. Theor. Appl. Genet. 2000, 100, 1121-1128. [CrossRef]

35. Yueqiu, H.; Wenhua, T.; Leung, H.; Zeigler, R.S. Identification of CO39 near-isogenic lines for rice blast. Zuo Wu Xue Bao 2001, 27, 838-841.

36. Xiao, N.; Wu, Y.; Pan, C.; Yu, L.; Chen, Y.; Liu, G.; Li, Y.; Zhang, X.; Wang, Z.; Dai, Z.; et al. Improving of rice blast resistances in Japonica by pyramiding major R genes. Front. Plant. Sci. 2017, 7, 1-10. [CrossRef]

37. Wu, Y.; Xiao, N.; Chen, Y.; Yu, L.; Pan, C.; Li, Y.; Zhang, X.; Huang, N.; Ji, H.; Dai, Z.; et al. Comprehensive evaluation of resistance effects of pyramiding lines with different broad-spectrum resistance genes against Magnaporthe oryzae in rice (Oryza sativa L.). Rice 2019, 12, 11. [CrossRef]

38. Xiao, N.; Wu, Y.; Wang, Z.; Li, Y.; Pan, C.; Zhang, X.; Yu, L.; Liu, G.; Zhou, C.; Ji, H.; et al. Improvement of seedling and panicle blast resistance in Xian rice varieties following Pish introgression. Mol. Breed. 2018, 38, 142. [CrossRef]

39. Singh, V.K.; Singh, A.; Singh, S.P.; Ellur, R.K.; Choudhary, V.; Sarkel, S.; Singh, D.; Krishnan, S.G.; Nagarajan, M.; Vinod, K.K.; et al. Incorporation of blast resistance into "PRR78", an elite Basmati rice restorer line, through marker assisted backcross breeding. Field Crop. Res. 2012, 128, 8-16. [CrossRef]

40. Ellur, R.; Khanna, A.; Yadav, A.; Pathania, S.; Hosahatti, R.; Singh, V.; Krishnan, S.; Bhowmick, P.; Nagarajan, M.; Kurungara, V.; et al. Improvement of Basmati rice varieties for resistance to blast and bacterial blight diseases using marker assisted backcross breeding. Plant. Sci. 2015. [CrossRef]

41. Khan, G.; Najeeb, S.; Bhat, Z.; Padder, B.A.; Parray, G.; Wani, S.; Shikari, A.; Kashmir, J. Molecular marker-based validation of blast resistance gene Pi54 and identification of potential donors in temperate high altitude rice (Oryza Sativa L.). Indian J. Genet. Plant. Breed. 2017, 77. [CrossRef]

42. Swathi, G.; Rani, C.; Md, J.; Satturu, V.; Anuradha, C.; Nagireddy, R.; Arunakumari, K.; Kumar, N.; Bhogadhi, S.; Eruvuri, R.; et al. Marker-assisted introgression of the major bacterial blight resistance genes, Xa21 and Xa13, and blast resistance gene, Pi54, into the popular rice variety, JGL1798. Mol. Breed. 2019, $39,58$. [CrossRef]

43. Kumar, P.N.; Sujatha, K.; Laha, G.S.; Rao, K.S.; Mishra, B.; Viraktamath, B.C.; Hari, Y.; Reddy, C.S.; Balachandran, S.M.; Ram, T.; et al. Identification and fine-mapping of Xa33, a novel gene for resistance to Xanthomonas oryzae pv. oryzae. Phytopathology 2012, 102, 222-228. [CrossRef] [PubMed] 
44. Brinkman, M.A.; Frey, K.J. Yield-component Analysis of Oat Isolines that Produce Different Grain Yields1. Crop. Sci. 1977, 17. [CrossRef]

45. Thiyagarajan, K.; Jeyaprakash, P.; Rajeswari, S.; Rabindran, R. CORH 3-A Short Duration Non aromatic rice hybrid. Electron. J. Plant Breed. 2009, 1, 1-5.

Publisher's Note: MDPI stays neutral with regard to jurisdictional claims in published maps and institutional affiliations.

(C) 2020 by the authors. Licensee MDPI, Basel, Switzerland. This article is an open access article distributed under the terms and conditions of the Creative Commons Attribution (CC BY) license (http://creativecommons.org/licenses/by/4.0/). 